Durmus, M., et al., Domates Bitkisi, Besin İçeriği ve Sağlık Açısından Değerlendirmesi.

International Journal of Life Sciences and Biotechnology, 2018. 1(2): p. 59-74.

\title{
Domates Bitkisi, Besin İçeriği ve Sağlık Açısından Değerlendirmesi
}

\author{
Mukaddes Durmus', Ozlem Yetgin', Mohamed Majed Abed ${ }^{1,2}$ Esmail Kelil Haji $^{1,4}$ \\ Kazım Akcay 1
}

Özet: Gıda arz temini yani beslenme ihtiyacı insanın yer kürede var olmasından bu yana en temel problemlerden biri olmuştur. Tarih boyunca sürekli tarım ve beslenmeye yönelik çalışmalar yapıllmış ve açlık sorununa çözümler bulunmaya çalışılmıştır. Özellikle ikinci dünya savaşından sonra yapılan devrim niteliğinde ki çalışmalar bu ihtiyaca cevap bulmak için yapılmış ve o dönem için kısa vadeli çözümler bulunulmasını sağlamıştır. Yapılan çalışmalar neticesinde kullanılan kimyasal maddeler, savaşlar neticesinde günümüzün önemli problemlerinden olan ağır metal stresi ve çevresel kirlilik günümüzde halen tedavisi mümkün olmayan çeşitli kanser ve kardiyovasküler hastalıklar gibi problemlerin ortaya çıkmasına neden olmuştur. Yapılan araştırmalar neticesinde bu problemler ile birlikte diyabetik hastalıklar, kalp krizi, inme gibi hastalıklar için kullanılabilecek tedaviler için zengin bir antioksidan kaynağı olan domates üzerinde çalışmaların daha da yoğunlaşmasına neden olmuştur. Likopenin anti-oksidatif ve anti kanser özelliklerinin keşfedilmesi ve domateste'de Likopenin bol miktarda bulunması, yüksek özdöllenme, melezmede, tozlaştırmada kolaylıklar bulunması ve özelliklede 2012 yılında genom çalışmaları tamamlanan domates bitkisi üzerinde birçok antioksidatif ve anti-kanser çareler bulmak için yapılan çalışmalarda ciddi oranda artış gözlendiği görülmüştür. Domatesin A ve C vitamini ile potasyum miktarı bakımından zengin olması domatesin kalori ve yağ oranının düşük olması ve kolesterol içermeyen lifli bir meyve olması da tercih edilebilirliğinin artıran başka bir neden olmuştur. Bu derlemede domates bitkisinin genel özellikleri ve üretim miktarları verildikten sonra besin içeriği ve sağlık üzerine etkilerine değinilmiştir.

Anahtar kelimeler: Domates, Likopen, anti-kanser, antioksidan, ß-karoten (beta karoten)

\section{Tomato Plant, Evaluation in terms of Nutrient Content and Healthy}

\footnotetext{
Abstract: The supply of food has become one of the most fundamental problems since the need for nutrition has existed in the globe. Throughout history, continuous agriculture and nutritional studies have been carried out and trying to resolve the problem of hunger. Especially after the second world war, revolutionary works were made to answer this need and provided short-term solutions for that period. According to result of many studies; chemical substances used, heavy metal stress as a result of wars and environmental pollution, which are one of the most important problems of our day, caused problems such as various cancer and cardiovascular diseases which are still untreatable. As a result of the researches, the problems along with diabetic diseases, heart attack, and stroke like diseases can be treated by using antioxidants which are abundant in tomato plant

${ }^{1}$ Ondokuz Mayıs Üniversitesi, Fen Bilimleri Enstitüsü, Tarımsal Biyoteknoloji Anabilim Dalı, Samsun

${ }^{2}$ Ondokuz Mayıs Üniversitesi, Ziraat Fakültesi, Tarımsal Biyoteknoloji Bölümü, Samsun

${ }^{4}$ Department of Plant Protection, Faculty of Agriculture, University of Anbar. Anbar, Iraq

${ }^{5}$ Department of Horticulture, College of Agriculture and Natural resource Management, Dilla University, Dilla, Ethiopia

*Sorumlu yazar:durmusmukaddes@ gmail.com
} 
and these led to further studies on the tomato as source of antioxidants. The discovery of the anti-oxidative and anti-cancer properties of lycopene and the high availability of lycopene in tomato, the high self-fertilization, hybridization, ease pollination of the crop and especially the studies of genome-wide tomato plants in 2012 seen that increased the rate to find many anti-oxidative and anti-cancer remedies. The fact that tomatoes are rich in vitamin $\mathrm{A}$ and vitamin $\mathrm{C}$; the calories and faty content of tomatoes are low and that they are a fiber-free fruit without cholesterol is another reason for increasing their preference. In this review, the characteristics and production amounts of tomato plants and their effects on nutrient content and health are given.

Key words: Tomato, Lycopene, anti-cancer, antioxidant, ß-carotene (beta carotene)

\section{Giriş}

İnsanoğlunun yeryüzünde var olduğundan beri tüm canlılarda olduğu gibi temel ihtiyaçlarının başında beslenme gelmektedir [1]. Kentselleşmenin hızla artması sonucunda nüfus yoğunluğu sebebiyle, su kaynaklarının ve tarıma elverişli alanların azalması, erozyonlar, gıda israfi, denizlerin kirlenmesi gibi birçok neden nüfusu besleyecek miktarda üretimi sağlayabilmek için gerekli olan ekilebilir alanların genişletilmesini zorlaştırmaktadır [2]. Bu nedenlerle ürün miktarının arttırılması ve yüksek üretim değeri bulunan tarım ürünlerinde üretimin arttırılması gerekli görülmüştür. Bundan dolayı insanlar günümüzde tükettiği sebze ve meyveleri besin ihtiyacını karşılamasının ötesinde içerdiği birtakım vitamin, mineral maddeler ve antioksidan özellikleri ile de değerlendirmeye başlamışlardır. İçerdikleri maddeler nedeniyle neredeyse sebzelerin tamamı insan sağlı̆̆ını koruyucu ve iyileştirici etkilere sahiptir. Bu sebzelerin başında da domates gelmektedir. Domates, taze olarak tüketilebildiği gibi; ketçap, salça ve sos gibi işlemiş olarak da yaygın bir şekilde kullanılabilmektedir [3]. Günümüzde ise bunlara ilaveten kurutulmuş domates başta olmak üzere domates suyu, püresi ve doğranmış hali de kolaylıkla tüketilebilir bir duruma gelmiştir.

Bu benzeri durumlardan dolayı domatesin değeri yıldan yıla artmıştır [3, 4]. Son olarak Arabidopsis veya çeltik bitkisi gibi model organizma olarak kullanılan bitkilerin aksine, 
model bitki olarak kullanılabilen domatesin birçok üstün özellikleri bulunmaktadır. Örneğin, domates bitkisi insan beslenmesi açısından önemli olan lifli meyveler üretmektedir [3, 5-7].

\section{Domates (Solanum lycopersicum L.) Bitkisinin Tarihçesi ve Üretim}

\section{Miktarları}

Domates bitkisi 24 kromozomlu diploid bir bitkidir. Patates, patlıcan, tütün, petunya ve biberler gibi ekonomik değeri olan bitkiler de dâhil olmak üzere 3000'den fazla tür içeren patlıcangiller ailesine aittir [7]. Domatesin 10.000 'den fazla çeşidi olduğu bilinmektedir. 1754'te Philip Miller domatesi Lycopersicum esculentum adıyla kendi ait türüne taşımıştır $[8,9]$. Domates ıslah çalışmaları ise yaklaşık 400 yıl önce başlamıştır dolayısı ile diğer patlıcangiller ailesine göre nispeten daha yeni bir çalışma alanı olmuştur. Islah çalışmalarının bu denli geç başlamasının birçok nedeni sayılabilir fakat en önemli nedenlerden birisinin domatesin bir zamanlar zehirli olduğunun kabul edilmesi ve bu nedenle tüketimine endişe ile bakılmış olmasından kaynaklandığı söylenebilir [10]. İlk başlarda domates 'mala aurea' (Altın Elma) bazende 'poma amoris' (Aşk Elması) olarak bilinmekteydi. Meksika'da 'tomatl' denilmekteydi ve buradan orijin alarak modern ismi tomato olarak adlandırılmıştır [11-13].

Kökünü And Dağlarından alan domates anavatanı Güney Amerika ülkelerinden Peru'dur. Avrupa'ya Amerika'nın keşfinden sonra 15. yüzyılda getirilmiştir. Günümüzde tüm dünyada yetiştirilen bir kültür bitkisidir ve üretim ile tüketimi artmaya devam etmektedir. Türkiye'ye domatesin gelişi ilk olarak 19. yüzyılda Fransa'nın ardından Suriye üzerinden olmuştur [3]. 


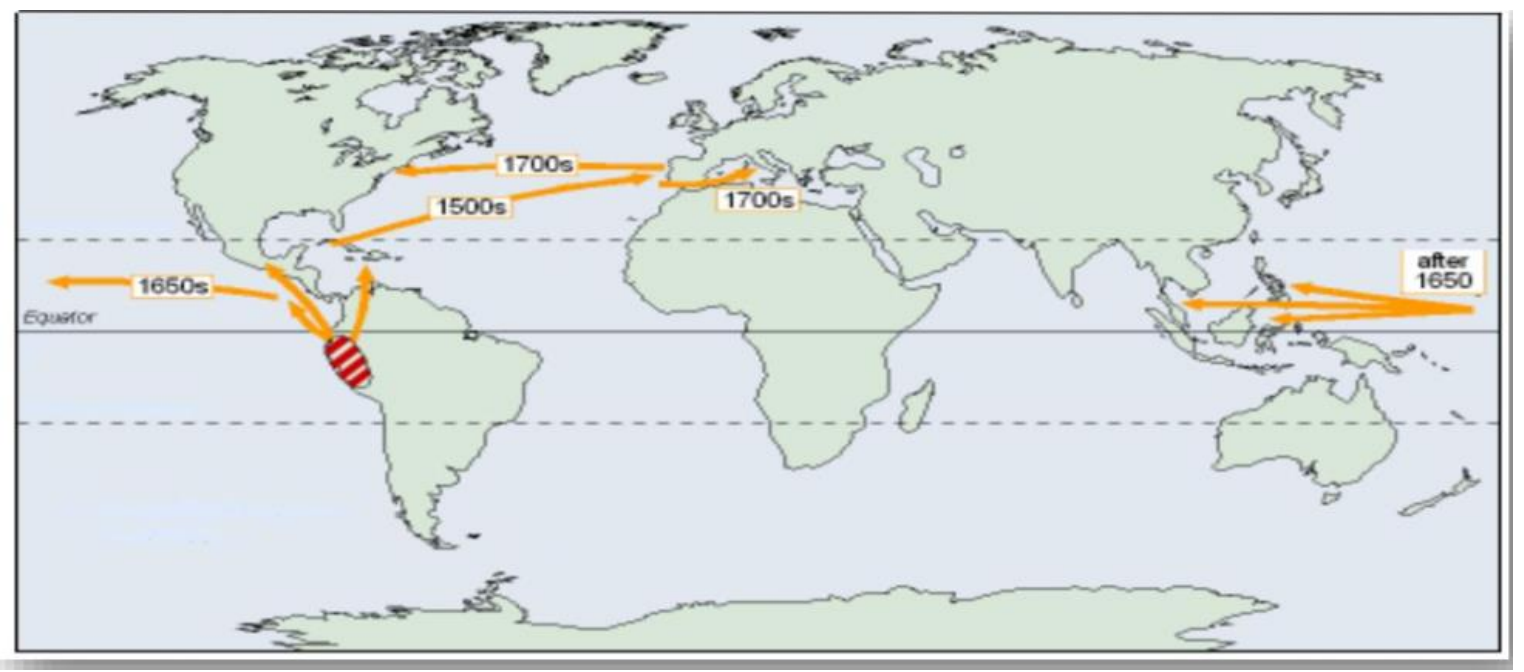

Şekil 1. Domates bitkisinin dünya ülkelerine dağılımı [14]

Domates (Solanum lycopersicum) dünya çapında bahçe bitkileri içerisinde en önemli 3 bitkiden bir tanesi olması yanında tüketim miktarı açısından da dünyanın en önemli sebzesi konumundadır $[15,16]$. Son 10 yıl içerisinde domates üretimi sürekli olarak artmıştır. Tüm yıllarda arazi ve seralarda domates üretiminin artmasıyla ekonominin büyümesinde önemli derecede etkili olmuştur. Domatesin kültüre alındığı ve dünyaya yayıldı̆̆g yer Avrupa olmasına rağmen Türkiye, Çin, Hindistan, $\mathrm{ABD}$ ve Mısır gibi ülkeler günümüzde dünyanın en önemli domates üreticilerinden olmuşlar ve Avrupa ülkelerini bu anlamda geride bırakmışlardır. Ayrıca bu ülkeler önemli üretim miktarları ile dünyada ilk sıralarda yer almaktadırlar. Türkiye 12,6 milyon ton domates üretimi ile Çin, Hindistan ve ABD' den sonra dördüncü sırada yer almaktadır (Tablo 1) [17]. 
Tablo 1. Dünyada en fazla domates elde eden ülkeler [18]

\begin{tabular}{|l|l|}
\hline Sıra & Üretim (ton) \\
\hline Çin & 57 milyon \\
\hline Hindistan & 19 milyon \\
\hline ABD & 15 milyon \\
\hline Türkiye & 12 milyon \\
\hline Mısır & 8 milyon \\
\hline İran & 6 milyon \\
\hline İtalya & 5 milyon \\
\hline İspanya & 4 milyon \\
\hline Brezilya & 3.8 milyon \\
\hline Meksika & 3.4 milyon \\
\hline
\end{tabular}

Türkiye'de domates üretiminde belli dalgalanmalar olsa da ortalama olarak y1llar boyunca sürekli bir artış içerisinde olduğu verilerden anlaşılmaktadır (Tablo 2).

Tablo 2. Yıllara göre Türkiye' deki domates üretim miktarları [17]

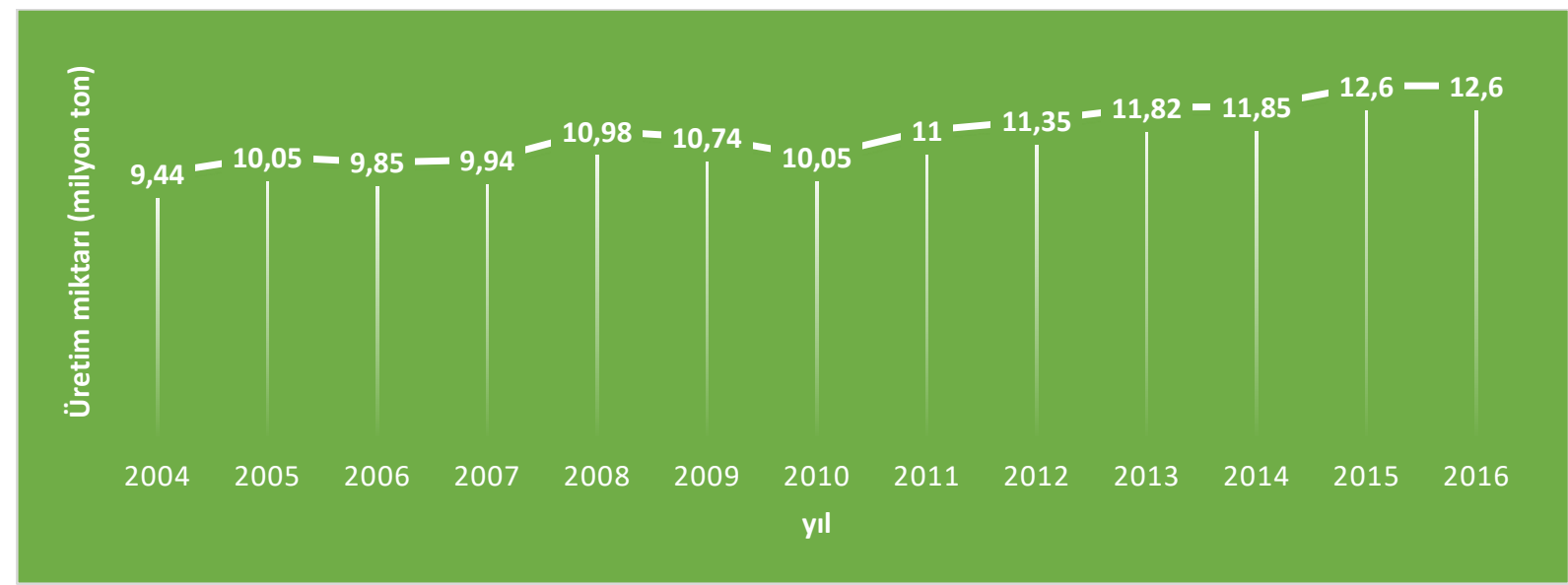

Çeşitli kullanım alanlarına sahip olmasından dolayı domatesin yurtiçinde kişi başına düşen tüketim miktarı ise 115-120 kg arasında değişkenlik göstermektedir (Tablo 3). 
Tablo 3. Türkiye Domates Verileri (bin ton) [19]

\begin{tabular}{|l|l|l|l|l|l|l|}
\hline & $\mathbf{2 0 1 2 / 1 3}$ & $\mathbf{2 0 1 3 / 1 4}$ & $\mathbf{2 0 1 4 / 1 5}$ & $\mathbf{2 0 1 5 / 1 6}$ & $\mathbf{2 0 1 6 / 1 7}$ & Değişim \\
\hline & & & & & & \\
\hline Alan ( 1000 ha) & 189 & 189 & 183 & 183 & $-3,5$ \\
\hline Üretim & 11.350 & 11.820 & 11.850 & 12.615 & 12.600 & 3,5 \\
\hline Yurt içi kullanım & 9.849 & 10.158 & 10.318 & 10.989 & - & $-6,5$ \\
\hline İthalat & 11 & 5 & & & & \\
\hline
\end{tabular}

Bundan dolayı domates üretiminde dördündü sırada olan ülkemiz domates ihracatında ise beşinci sırada yer almaktadır (Tablo 4). İhracat yapılan ülkelerde ise Belarus birinci sırada, Irak ise ikinci sırada gelmektedir [19].

Tablo 4. Türkiye'nin domates ihracat yaptığı ülkeler

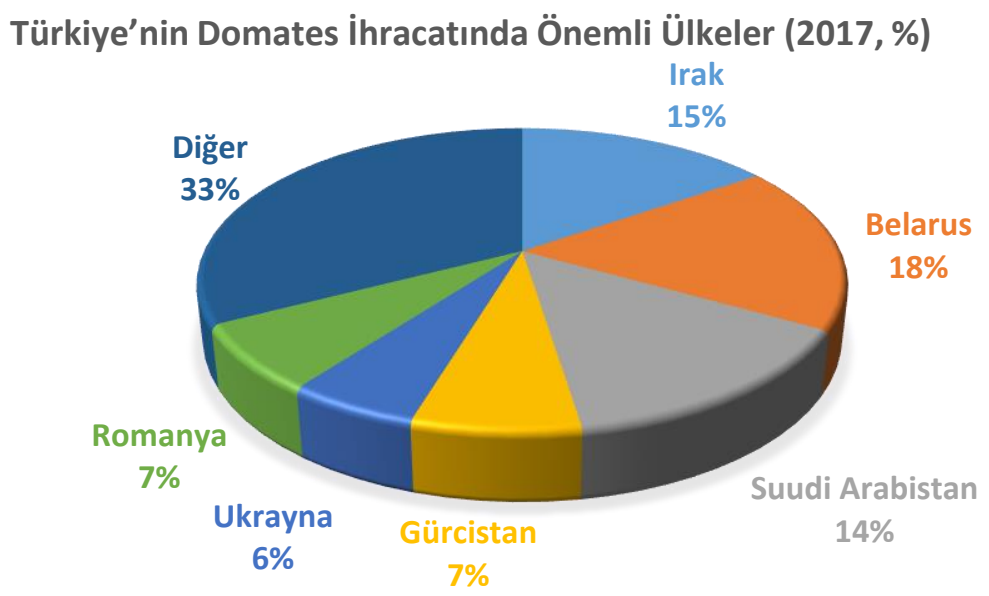


Bunlara ilaveten domates bitkisinin güçlü besin içeriğinden dolayı bazı genleri kullanılarak dikotiledon kültür bitkilerinde uygulamak ve yeni çeşitler geliştirmek için model bir bitki olarak da kullanılabilmektedir [20]. Farklı yetiştirme koşullarındaki büyüme ihtimali, nispeten kısa yaşam döngüsü, tohum üretim yeteneği, nispeten küçük genomu (950 Mega

bayt), gen kopyalama, yüksek öz-döllenme, homozigotluk, tozlaştırma, melezlemedeki kolaylığı, aşılamayla yapılan eşeysiz üreme yeteneği ve farklı besin içeriklerinden oluşan doku kültürlerinde yetişmesi, totipotensi özelliğinin bulunmasından dolayı tam bir bitki eldesi, genom çalı̧̧malarının tamamlanması gibi birçok sayıda farklı özelliği barındırmasından dolayı domatesin model bitki olarak kullanılmasında ön plana çımasını sağlamıştır [5, 21-26].

\section{Domatesin Besin İçeriği ve Sağlık Üzerine Etkisi}

Domates meyvesi içerdiği besin miktarları olarak; karotenoidler, lipitler, organik asitler (sitrik asit ve malik asit), \%93-95 su, alkolde çözünemeyen katı maddeler (proteinler, selüloz, pektin, polisakkaritler), \%5-7 oranında da inorganik bileşiklerden oluşmaktadır [5, 27]. Domates zengin bir mineral, vitamin, organik asit, esansiyel aminoasit ve besin lifi kaynağıdır. Ayrıca zengin vitamin A, vitamin C ve potasyum mineral kaynăğ olup, demir ve fosfor gibi mineralleri de içerir. Domatesin kalori ve yağ oranı düşüktür, kolesterol içermeyen iyi bir besin lif kaynağıdır [28]. Domates kendine has besin değeri sayesinde, yani likopen, beta karoten, flavanoidler içerdiğinden koruyucu bir bitki olarak görülür. Özellikle son yıllarda likopenin anti-oksidatif faaliyetleri ve anti- kanser fonksiyonlarından dolayı dev bir popülarite elde etmiştir $[29,30]$. Bu yüzden üretim ve tüketimi sürekli artmaktadır. 
Glukoz ve fruktoz miktarı yüksek, eser miktarda sakkaroz bulunduran olgun taze domates meyvesindeki pektinler, ksilanlar, arabinoksilanlar ve selüloz, en önemli polisakkratlerdir. Taze domates suyundaki serbest aminoasitlerin $\% 45$ 'ini glutamik asit oluşturmakta, bunu aspartik asit izlemektedir. Sitrik asit en fazla bulunan organik asit iken bir miktarda malik asit bulunmaktadır [3, 31]. Domatesin tadı ve aroması üzerinde etkili olan 400'ün üzerinde madde bulunmuş, bunların 30 tanesinin aroma oluşumunda çok daha yüksek etkisinin olduğu belirlenmiştir. Uçucu ve değişken aroma maddelerinin ve organik asitlerin yanında şekerler, serbest aminoasitler, mineral tuzları da domatesin tadının oluşumunda rol oynamaktadır. Domatese kırmızı rengini veren metabolit ise, başta likopen olmak üzere karotenoidlerdir. Tüm bu metabolitlerin miktarı; türler, olgunluk aşaması, iklim şartları, sıcaklık, 1şık, toprak, gübreleme, sulama ve yetiştiricilik sırasında yapılan diğer işlemler, hasat ve depolama koşullarına göre farklılık gösterebilmektedir [4].

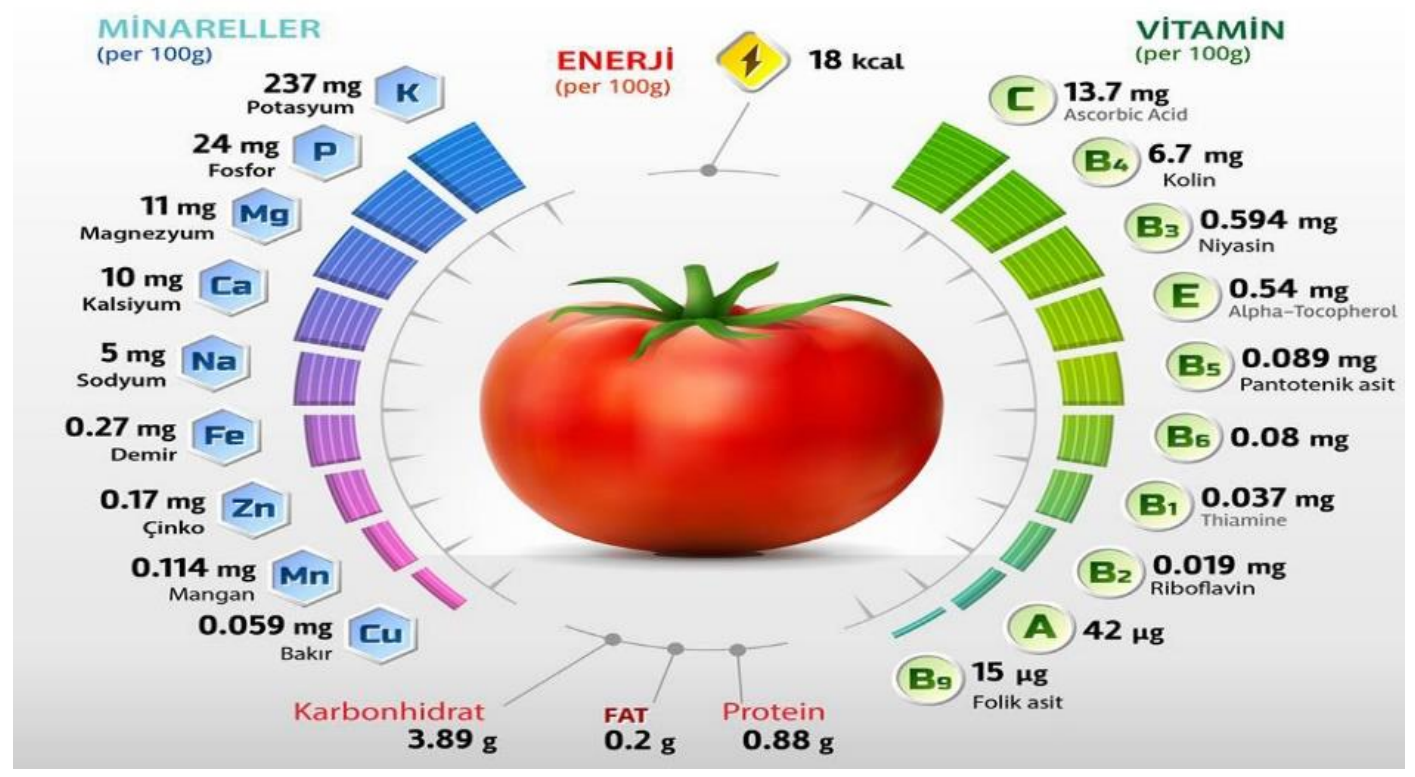

Şekil 3. Domates meyvesinin besin içeriği [18] 
Domates birçok fitokimyasal içermektedir fakat en çok bilineni likopendir. Likopen; havuç, karpuz, kuşburnu, kestane kabağı, pembe greyfurt, papaya ve pembe guava gibi diğer sebze ve meyvelerde, hatta bazılarında domatesten daha fazla bulunmasına rağmen yıl içinde tüketim miktarı göz önüne alındığında "likopenin kaynağı" domates olarak kabul edilmektedir. Likopen, olgun domates meyvesinin kırmızı renge dönüşümünü sağlamakta ve önem arz etmektedir [32, 33]. Ayrıca likopenin yanı sıra diğer karotenler (örneğin $\beta$-karoten), C ve $\mathrm{E}$ vitamini ve diğer fenolik bileşikler de insan sağlı̆ını destekleyen maddeler olduklarından dolayı sanayi ve tüketiciler için domatesin tercih edilmesini artırmakta ve kalitesi için göz önünde bulundurulmaktadır [34-36].

Likopen biyoyarayışl1lı̆ğ bir dizi faktörden etkilenebilir: gıda matrisinin parçalanması, pişirme sıcaklığı, lipitlerin varlığı, dozaj ve diğer karotenoidler dahil diğer çözünebilir bileşikler. Bu faktörler, likopenin gıda matriksinden salınmasına neden olur ve böylece biyoyarayışlılığını artırırlar. İşleme ve depolamanın likopen yapısı ve stabilitesi üzerindeki etkileri bir dizi nedenden ötürü ilgi çekicidir. Uygun olmayan işlem ve depolama (yani, ışığa ve oksijene maruz kalma), likopen izomerlerinin oranını değiştirebilir veya likopeni tamamen bozabilir ve bu gıda ürünlerini tüketiciye daha az cazip kılabilir. Likopen'in izomerizasyonu emilim verimliliğini etkiler [37-39].

Geleneksel ticari işlem yöntemleri, likopen seviyeleri veya cis / trans izomerizasyonu üzerinde önemli bir etkiye sahip değildir. Aslında, 1sıl işlem, genellikle, likopenin doku matrisinden salınmasına izin veren, hücresel zarları bozarak, likopen biyoyararlanımını geliştirir. Birçok çalışma, termal olarak işlenmiş domates ürünlerinden alınan likopenin taze domateslerden likopenden daha fazla yararlanabileceğini göstermiştir. Likopen 
biyoyarayışlığı, diyet kompozisyonundan büyük ölçüde etkilenir. Likopenin bir lipitçözünebilir bileşik olduğu göz önüne alınırsa, yă̆ ile tüketilmesi biyoyararlanımını arttırır [40]. Oksidanlar; DNA, proteinler ve hücre dokularını olumsuz yönde etkileyen kimyasal ajanlara karşı savunma sırasında oluşmakta ve vücutta normal metabolizma işlevlerinde hasara yol açmaktadır yani oksidatif yıkıma neden olmaktadırlar. Vücutta görülen bu oksidatif yıkım belirtilerine yaşlanma, kardiyovasküler hastalıklar, bağışıklık sisteminde zayıflama gibi olumsuz durumlar gösterilebilir. Ayrıca oksidanların katarakt hastalığının temel nedeni olarak gösterildiği bazı çalışmalarda bulunmaktadır [41]. Günümüzde güçlü bir antioksidan özelliği bulunan likopenin sağlık üzerine etkilerinin araştırıldığı birçok çalışma bulunmaktadır. Antioksidanlar serbest radikallerin nötralize edilmesini sağlayarak DNA, protein ve lipidler gibi hücre bileşenlerinin serbest radikallerden zarar görmesini engellemektedir [42]. Likopen, diğer karotenoidler ile kıyaslandığında özellikle tekli oksijeni yakalamada daha etkilidir. Karotenoidler, aktif radikalleri elektron transfer ederek, hidrojen vererek ya da radikale bağlanarak inhibe edebilmektedir [4, 43]. $\beta$-karoten, bir zincir kırıcı antioksidan olarak çok önemli bir fonksiyon sağlamasına rağmen oksijen basıncının artmasıyla antioksidan etkinliğinin azaldığı yapılan bazı çalışmalarda belirtilmiştir [3, 44]. Bunlara ilaveten vücutta ki karotenoid miktarı ile kalp damar tıkanıklığı, kemik kalsifikasyonu ve sinirsel rahatsızlıklar gibi bazı hastalıkların görülme riskinin önemli miktarda azalma gösterdiği bazı çalışmalarda belirtilmiştir. Dolayısıyla karotenoid miktarı ve bazı hastalıklar arasında kuvvetli ilişki olduğu yapılan çalışmalarda görülmüştür [45]. Domateste sayılan besleyici özelliklere ilaveten domatesin yapısında bulunan $\beta$-karoten, phytoene, phytofluene gibi karotenoidler, kumarik ve klorojenik asitler gibi fenolik bileşikler, bol miktarda $\mathrm{C}$ vitamini (askorbik asit) ve tokoferol (E vitamini) de domatesin 
besleyici değerini artıran yapılardır. Yapılan çalışmalarda domates üzerinde yapılan çalışmalar incelendiğinde domateste bulunan fitokimyasalların sağlık üzerinde etkilerinin belirlenmeye yönelik çalışmaların az, $\beta$-karotenin A vitaminin önemli bir öncül bileşeni olduğu ve likopen gibi, kanseri önlemede rol oynamasından dolayı daha çok olduğu görülmüştür [46, 47]. Son olarak domateste bulunan önemli antioksidanlardan olan flavonoidler gibi fenolik bileşiklere değinecek olursak; fenollik bileşenler; anti-alerjik, antiinflamatuar, anti-mikrobiyal ve anti- kanser özelliklere sahiptirler domates tohumunun etrafını saran ve jelatinimsi yapıdaki maddenin pıhtı veya damar tıkanıklığını (trombosit agregasyonu) gidermede, felç (inme) ve kalp krizi gibi problemlerin ortaya çıkmasını engellediği belirtilmiştir. Domatesin içerdiği zengin vitamin ve protein kaynakları gibi içeriğinden dolayı geçmişten günümüze tıbbi anlamında kullanılmıştır [4]. Başlıca sağlık üzerine etkileri ise;

\section{$\checkmark$ Diyabetik rahatsızlıklar}

1990'ların sonlarından beri, çeşitli temel çalışmalar ve klinik araştırmalar, domatesleri tip 2 diyabetle ilişkilendirmiştir. Domatesin (taze veya pişmiş) diyabetik rahatsızlıklar için yararlı olduğu bulunmuştur. Çünkü diyabet kaynaklı oksidatif stres, iltihaplanma ve doku (yani retina, böbrek ve kas-iskelet sistemi) hasarını azaltır. İnsanlarda yapılan daha ileri çalışmalar, domatesin veya bunun türetilmiş bileşiklerinin diyabetik koşullardaki hipoglisemik yanıtını ortaya çıkarmak için çok önemlidir. Özellikle tip 2 diyabet, küresel bir sağlık sorunudur, çünkü bu hastalığa sahip kişilerin sayısı her yıl artmaktadır [48]. Bu nedenle, diyabetin yönetilmesi veya önlenmesi için etkili bir terapi veya ev ilaçlarını inceleyen herhangi bir araştırma ya da rapor oldukça önemlidir. Dünya Sağlık Örgütü uzman paneli, bitki kökenli 
anti hiperglisemik gıdaların ve ajanların araştırılmasını, taranması ve raporlanmasını tavsiye etmiştir. Ek olarak, diyetin tip 2 diyabet riski ile yakından ilişkili olduğu iyi bilinmektedir ve birçok çalışma, tip 2 diyabet vakalarının sağlıklı bir diyetin (yani sebzeler açısından zengin bir diyet) takip edilmesiyle önlenebileceği hipotezini desteklemektedir. Yapılan çalışmalar domatesin (taze veya pişmiş) veya likopen, kaempferol ve naringenin gibi türetilmiş bileşiklerinin diyabet kaynaklı oksidatif strese karşı güçlü antioksidan etkiler gösterdiğini göstermektedir [49]. Bu antioksidan etki esas olarak antioksidan enzimlerin aktivitesinin arttırılması, enzimatik olmayan antioksidanların seviyesinin arttırılması ve reaktif oksijen türlerinin (yani $\mathrm{H}_{2} \mathrm{O}_{2}$ ) oluşumunun azaltılmasıyla ortaya çıkar [13, 31].

\section{$\checkmark$ Çeşitli kanserler ve kardiyovasküler hastalıklar}

Domates ve domates ürünlerinin tüketimi, özellikle prostat, akciğer ve mide gibi bir dizi farklı tipte kanserin azalması ile ilişkili bulunmuştur. Gelişmiş ülkelerin çoğunda kardiyovasküler hastalık $(\mathrm{KVH})$ önde gelen ölüm nedenidir. Bazı klinik çalışmalar da kardiyovasküler hastalık ve likopen alımı arasındaki ilişkiyi desteklemiştir. Gajendragadkar ve diğ. bir "Akdeniz diyeti” nin kardiyovasküler hastalı̆̆ı (KVH) azalttığı mekanizmaları incelediler ve CVD hastalarında ve ayrı ayrı, sağlıklı gönüllülerde (HV) likopenin vaskülatür üzerindeki etkilerini araştırmaya çalıştılar [50]. Tavsiye edilen günlük likopen alımı, iki bardak domates suyu veya domates ürünleri kombinasyonu ile elde edilebilen 35 mg olarak belirlenmiştir. Bu gidalar hem kemoperapötik hem de kemoterapötik değerlere sahip olabilir $[46,51,52]$.

\section{Sonuç}


Domates (S. Lycopersicum L.) tüketiminin yapılmaya başlandığı zamanlardan bu yana küresel olarak önemini ve değerini sürekli korumuş bir bitki olmuştur. Kullanımı ve faydaları bilindikçe domatese olan ilgi artmış bunun neticesinde ekim alanı ve üretimi de sürekli artış göstermiştir. Domates ham ve işlenmiş ürün olarak tüketilebildiği için günümüzde çok farklı kullanım alanlarına sahip olmuştur. İki bin (2000)'li yılların başlarından itibaren artış gösteren ve tedavisi henüz mümkün olmayan çeşitli kanser, diyabetik ve kardiyovasküler hastalıkların protein ve hücre dokularının tahribini durdurmak için antioksidan aktivitesi yüksek ürünlerin tüketiminin yapılması ise Likopen içeriğinden dolayı domates bitkisine olan ilgiyi daha da artırmıştır. Likopen vücutta kansere sebebiyet veren serbest radikallerin vücuttan uzaklaştırılmasında oldukça etkilidir. Domates kullanılarak kanser hastalığına çareler bulmaya yönelik yapılan çalışmalarda prostat, rahim, mide, mesane, göğüs, ağız ve daha birçok kansere karşı etkili olduğu görülmüştür. Kanser hastalığı dışında domateste yapılan çalışmalarda görülen sonuçlara; günlük $\mathrm{C}$ vitaminin $\% 40$ a yakınını temin edebilmesinden dolayı vitamin ve mineral içeriği bakımından zengin olması, kardiyovasküler hastalıklara neden olan serum lipid oksidasyonunu önleyerek kolesterolü dengelemesi ve kalbi koruması, vücutta üretilen ve sigara içeriğinde de bulunan nirosaminlere karşı kumarik asit ve klorojenik asit gibi ihtiyaçaların temini ile vücudu sigaranın zararlarından korumakta ve sigaranın zararlarını en aza indirgemesi örnek olarak gösterilebilir. Bunların dışında zengin A vitamini deposu olmasından dolayı gözler için çok faydalı olması, hazım kolaylaştırması bakımından sindirim sistemine yardımcı olması, potasyum içeriğinden dolayı hiper tansiyon riskini azaltması, oksidatif stresin azalmasını sağlamasından dolayı 2. tip diyabete karşı etkili bir biçimde kullanılabilmesi, cilt için faydalı olması ve idrar yolu enfeksiyonlarından koruması da domatesin sağlığa faydaları arasında sayılabilmektedir. 
Bütün bu sayılan faydalarından dolayı ıslah çalışmaları bakımından karotenoidler ve özellikle likopen içeriği yüksek yeni çeşitlerin geliştirilmesi ve ticaretinin yapılması sağlanmalıdır. Günümüzde yoğun iş temposu ve şehir hayatının yorucu stresi altında oksit oranı artan vücutta antioksidan tüketimine daha çok ihtiyaç duyulacağı ve birçok önemli hastalığın önlenmesinde antioksidanlar ile çareler bulunacağı aşikardır. Dolayısı ile domates ve besin içeriğinin muhafaza edilmesi ve yeni çeşitlerin geliştirilmesi gün geçtikçe daha da önemli hâle gelecektir.

Geliş Tarihi: 13.11 .2018

Kabul Tarihi: 13.12 .2018

\section{Kaynaklar}

1. Yüksek, A., İslam Hukukuna Göre Helal Gıda ve GDO’lu Ürünler. (Genetiği Değiş̧tirilmiş Organizmalar). 2018, Bişkek: İz Basma.

2. Arvas, Y.E., Genetiği Değiştirilmiş Bitkiler ve Tanısı. 2017, Düsseldorf, Germany: Lambert Yayınevi.

3. Al-Remi, F., et al., Domates Bitkisi Ve in Vitro Mikro Çoğaltımı (Tomato Plant and Its In Vitro Micropropagation). Journal of Engineering Technology and Applied Sciences, 2018. 3(1): p. 55-73.

4. Sönmez, K. and Ş.Ş. Ellíaltioğlu, Domates, karotenoidler ve bunları etkileyen faktörler üzerine bir inceleme. Derim, 2014. 31(2): p. 107-130.

5. Minoia, S., et al., A new mutant genetic resource for tomato crop improvement by TILLING technology. BMC research notes, 2010. 3(1): p. 69.

6. TomatoGenomeConsortium, The tomato genome sequence provides insights into fleshy fruit evolution. Nature, 2012. 485(7400): p. 635-641.

7. Bai, Y. and P. Lindhout, Domestication and breeding of tomatoes: what have we gained and what can we gain in the future? Annals of botany, 2007. 100(5): p. 1085-1094.

8. Foolad, M.R., Genome mapping and molecular breeding of tomato. International Journal of Plant Genomics, 2007. 2007.

9. Peralta, I.E. and D.M. Spooner, History, origin and early cultivation of tomato (Solanaceae). Genetic improvement of solanaceous crops, 2006. 2: p. 1-27.

10. Günay, A., Sebze yetiştiriciliği. Cilt-II, Meta Basımevi, İzmir, 2005.

11. FAOSTAT. 2011; Available from: http://faostat3.fao.org/faostat-gateway/go/to/download/Q/QC/E.

12. Goodenough, P.W., Tomato, cucumber and gherkin. Elsevier Science, 1991: p. pp.327-350.

13. Çakıroğlu, M., Metabolic and genomic profiling for taste and aroma traits in tomato (Solanum lycopersicum). 2017, İzmir Institute of Technology.

14. Anonymous. FAOSTAT. Agriculture Production Data. 2014; Available from: http://faostat.fao.org. [Erişim tarihi: 29.08.2018].

15. Dorais, M., et al., Greenhouse tomato fruit cuticle cracking. Horticultural Reviews, Volume 30, 2004 : p. $163-184$.

16. Tatar, M. and V. Pİrİnç, Türkiye Güneydoğu Anadolu Bölgesi'nin Sanayi Domatesi Üretim Potansiyeli. Iğdır Üniversitesi Fen Bilimleri Enstitüsü Dergisi, 2017. 7(2): p. 11-20.

17. FAO. Statistical Pocketbook World Food and Agriculture. Food and Agriculture Organisation of the United Nations. . 2017; Available from: http://www.fao.org/land-water/databases-and-software/en/ [Erişim Tarihi: 30.10 .2018$]$. 
18. USDA. National Nutrient Database for Standard Reference Release 28. 2017; Available from: https://ndb.nal.usda.gov/ndb/foods/show/3223 [Erişim Tarihi: 29.10.2018].

19. TAGEM. Tarım Ürünleri Piyasaları Domates. Tarımsal Ekonomi ve Politika Geliştirme Enstitüsü (TAGEM). 2018; Available from: https://arastirma.tarimorman.gov.tr/tepge/Belgeler/PDF\%20Tar\%C4\%B1m\%20\%C3\%9Cr\%C3\%BC nleri\%20Piyasalar\%C4\%B1/2018-

Ocak\%20Tar\%C4\%B1m\%20\%C3\%9Cr\%C3\%BCnleri\%20Raporu/2018-Ocak\%20Domates.pdf

[Erişim Tarihi: 28.10.2018].

20. Paduchuri, P., et al., Transgenic tomatoes - a review. Int J Adv Biotechnol Res, 2010. 1: p. 69-72.

21. Consortium, T.G., The tomato genome sequence provides insights into fleshy fruit evolution. Nature, 2012. 485(7400): p. 635.

22. Martí, E., et al., Genetic and physiological characterization of tomato cv. Micro-Tom. Journal of experimental botany, 2006. 57(9): p. 2037-2047.

23. Saito, T., et al., TOMATOMA: a novel tomato mutant database distributing Micro-Tom mutant collections. Plant and cell physiology, 2011. 52(2): p. 283-296.

24. Dorais, M., et al., Greenhouse tomato fruit cuticle cracking. Hort. Rev, 2004. 30: p. 163-184.

25. Kobayashi, M., et al., Genome-wide analysis of intraspecific DNA polymorphism in 'Micro-Tom', a model cultivar of tomato (Solanum lycopersicum). Plant and Cell Physiology, 2014. 55(2): p. 445454.

26. Sant'Ana, D.V.P. and M. Lefsrud, Tomato proteomics: Tomato as a model for crop proteomics. Scientia Horticulturae, 2018. 239: p. 224-233.

27. Petro-Turza, M., Flavor of tomato and tomato products. Food Reviews International, 1986. 2(3): p. 309-351.

28. Kabelka, E., W. Yang, and D.M. Francis, Improved tomato fruit color within an inbred backcross line derived from Lycopersicon esculentum and L. hirsutum involves the interaction of loci. Journal of the American Society for Horticultural Science, 2004. 129(2): p. 250-257.

29. Seçgin, Z., et al., Selection of Root-Knot Nematod Resistance in Inbred Tomato Lines Using CAPS Molecular Markers. International Journal of Life Sciences and Biotechnology. 1(1): p. 10-16.

30. Raiola, A., et al., Enhancing the health-promoting effects of tomato fruit for biofortified food. Mediators of inflammation, 2014. 2014.

31. Durmuş, M., Domates Bitkisinde Biyoteknolojik Çalışmalar ve GDO Tanısı, in Tarımsal Biyoteknoloji Anabilim Dalı. 2018, Ondokuz Mayıs Üniversitesi: Samsun. Türkiye.

32. Figueiredo-González, M., et al., Further insights on tomato plant: Cytotoxic and antioxidant activity of leaf extracts in human gastric cells. Food and Chemical Toxicology, 2017. 109: p. 386-392.

33. Figueiredo-Gonzalez, M., P. Valentao, and P.B. Andrade, Tomato plant leaves: From by-products to the management of enzymes in chronic diseases. Industrial crops and products, 2016. 94: p. 621-629.

34. Lopez, J., et al. Color and lycopene content of several commercial tomato varieties at different harvesting dates. in VII International Symposium on the Processing Tomato 542. 2000.

35. Dumas, Y., et al., Effects of environmental factors and agricultural techniques on antioxidantcontent of tomatoes. Journal of the Science of Food and Agriculture, 2003. 83(5): p. 369-382.

36. Aksoy, H.M., et al., Pseudomonas putida-Induced response in phenolic profile of tomato seedlings (Solanum lycopersicum L.) infected by Clavibacter michiganensis subsp. michiganensis. Biological Control, 2017. 105: p. 6-12.

37. Misra, B.B. and S. Dey, Phytochemical Analyses and Evaluation of Antioxidant Efficacy of in vitro Callus Extract of East Indian Sandalwood Tree (Santalum album L.). Journal of Pharmacognosy and Phytochemistry, 2012.

38. Marques, C., et al., Tomato Lycopene: Functional Proprieties and Health Benefits. World Academy of Science, Engineering and Technology, International Journal of Biological, Biomolecular, Agricultural, Food and Biotechnological Engineering, 2015. 9(10): p. 1089-1099.

39. Ganesh, N., K. Lakshmi, and V. Chandy, Lycopene properties, and its benefits in human health: a brief review. WJPPS, 2016. 5: p. 424-436.

40. Hwang, E.-S. and P.E. Bowen, Can the consumption of tomatoes or lycopene reduce cancer risk? Integrative cancer therapies, 2002. 1(2): p. 121-132. 
41. Kopsell, D.A. and D.E. Kopsell, Accumulation and bioavailability of dietary carotenoids in vegetable crops. Trends in plant science, 2006. 11(10): p. 499-507.

42. Stewart, W., Balanced fertilization increases water use efficiency. News \& Views. A regional newsletter published by the Potash \& Phosphate Institute (PPI) and the Potash \& Phosphate Institute of Canada (PPIC). 2001, Lubbocks Texas.

43. Simpson, K.L., Chemical changes in natural food pigments, in Chemical changes in food during processing. 1985, Springer. p. 409-441.

44. Krinsky, N.I. and E.J. Johnson, Carotenoid actions and their relation to health and disease. Molecular aspects of medicine, 2005. 26(6): p. 459-516.

45. Barba, A.O., et al., Application of a UV-vis detection-HPLC method for a rapid determination of lycopene and $\beta$-carotene in vegetables. Food Chemistry, 2006. 95(2): p. 328-336.

46. Navarro-González, I., J. García-Alonso, and M.J. Periago, Bioactive compounds of tomato: Cancer chemopreventive effects and influence on the transcriptome in hepatocytes. Journal of Functional Foods, 2018. 42: p. 271-280.

47. Agarwal, A., et al., Lycopene content of tomato products: its stability, bioavailability and in vivo antioxidant properties. Journal of medicinal food, 2001. 4(1): p. 9-15.

48. Banihani, S.A., Tomato (Solanum lycopersicum L.) and type 2 diabetes. International Journal of Food Properties, 2018. 21(1): p. 99-105.

49. Shidfar, F., et al., The effects of tomato consumption on serum glucose, apolipoprotein B, apolipoprotein AI, homocysteine and blood pressure in type 2 diabetic patients. International journal of food sciences and nutrition, 2011. 62(3): p. 289-294.

50. Gajendragadkar, P.R., et al., Effects of oral lycopene supplementation on vascular function in patients with cardiovascular disease and healthy volunteers: a randomised controlled trial. PLoS One, 2014. 9(6): p. e99070.

51. Bulling, K., Engineering of polyphenol metabolism in tomatoes to enhance anti-cancer activities. 2013, University of East Anglia.

52. Bakir, S., et al., Tomato Polyphenolics: Putative Applications to Health and Disease, in Polyphenols: Mechanisms of Action in Human Health and Disease. 2018, Elsevier. p. 93-102. 